doi: 10.17492/pragati.v3i2.7744

\title{
Performance of Regional Rural Banks in Indian Economy: An Overview
}

\author{
Bhajan Chandra Barman*
}

\begin{abstract}
Regional Rural Banks (RRBs) also known as 'Gramin' bank have emerged as an important rural credit delivery institution in India for meeting the credit requirements of the rural poor. These rural banks have been working for more than four decades in the Indian rural credit delivery system. They are state sponsored, regionally based and rural oriented commercial banks. The basic objective of this study is to analyse the growth and financial performance of RRBs in India from the period 2013 to 2016 based on some selected parameters like area coverage, profit and loss making RRBs, trends of profits and accumulated losses, overall position of non-performance assets and recovery rate. We have mainly used secondary data collected from various journals, books and available websites related to regional rural banks. The review of performance of RRBs shows the good growth performance of RRBs for providing better banking services to the rural people. From the analysis, we can draw the conclusion that rapid expansion of RRBs has been able to substantially reduce the regional disparities in respect of banking facilities in India.
\end{abstract}

Keywords: Regional Rural Banks, Rural Credit, Deposit, Financial Performance.

\subsection{Introduction}

It is well-known that commercial banks and co-operative banks have achieved a great success in the area of financing during the post-Independence period. However, the rural poor did not have any banking facilities from the commercial as well as cooperatives banks during that time. Commercial banks did not find much interest in penetrating rural areas. Cooperatives societies lacked competence needed for the steadily growing rural industries and tertiary sectors of the rural economy. As it is, the cooperative system has hardly touched the small traders and shopkeepers, repair workshops, artisans.

*Assistant Professor, Department of Economics, Netaji Nagar College, Kolkata, West Bengal.(email: bhajanbarman@gmail.com) 
In 1975, after the identification of various weaknesses of the cooperative credit agencies and the commercial banks, it was felt that these institutions would not be able to fill the regional and functional gaps in the rural credit system. There exists a wide gap between demand and supply of rural credit. Rural poor are forced to borrow from the money lenders at exorbitant interest rate. In order to bridge this gap between demand and supply of rural credit and to save the rural poor from the money lenders, a new type of institution was recommended with a local feel and familiarity. It also had a degree of business organisation ability to mobilise deposit, access to money market and modernise outlook. In this way, a new a set of banks namely regional rural banks were introduced in banking sector of India.

Rs.Regional Rural Banks (RRBs) also known as gramin bank emerged as an important rural credit delivery institution in India for meeting the rural credit requirement of the rural poor. These rural banks have been working for more than four decades in the Indian rural credit delivery system. They are state sponsored, regionally based and rural oriented commercial banks. The Regional Rural Banks Ordinance was passed on 26 September 1975, which was later replaced by the Regional Rural Banks Act, 1976. Initially, five RRBs were established on October 2, 1975 at Moradabad and Gorakpur in Uttar Pradesh, Bhiwani in Haryana, Jaipur in Rajasthan and Malda in West Bengal. RRBs are small, region based; rural development oriented public sector commercial banks. They mainly lend to small and marginal farmers, agricultural labourers, artisans, small traders and entrepreneurs in the rural area to generate income, employment and development.

The paper is divided into six sections. Section 1 has introduced the topic. Sections 2 and 3 deal with review of literature and resources of RRBs respectively. Section 4 outlines the objectives, data and methodology. Section 5 analyses the performance of Regional Rural Banks and section 6 concludes.

\subsection{Review of Literature}

The literature available in the working and performance of RRBs in India is somewhat limited. The literature obtained in the form of reports of various committees, commissions and working groups established by the Union Government, NABARD and Reserve Bank of India, the research studies, articles of researchers, bank officials, economists and the comments of economic analysts and news is briefly reviewed in this part. 
Ibrahim (2010) made an attempt to investigate whether the amalgamation of Regional Rural Banks in India has helped to improve their performance. In his study, some performance indicators have been used such as number of banks and branches, capital composition, deposits, loans and trends of investments. The study found that performance of rural banks in India has significantly improved after amalgamation process which was initiated by the Government of India.

Selvakumar (2010) has shown the performance of Regional Rural Banks in Tamil Nadu, in comparison with the RRBs at the all India level. He made a comparative study of deposits, loans, income, expenditure and profitability of RRBs in India and RRBs in Tamil Nadu. The study revealed that there is a significant difference in growth rates of advances to service sector and advances to priority sector by 18 RRBs in India and RRBs in Tamil Nadu. He states that this was due to the better performance of RRBs in Tamil Nadu.

Ishwar (2011) made an attempt to study the performance of the RRBs from 1980-81 to 2008-09. In order to know the implications of transformation of RRBs in 2004 , the study focused on financial results before and after amalgamation. The findings of the study revel that after amalgamation, RRBs transformation had resulted in a 200 per cent increase in net profits, and a 100 per cent increase in business. There was a gradual reduction in the number of loss-making banks and addition of 1,000 outlets. All this had been because of consolidation among RRBs.

Bhatt (2013) conducted a study that focused on western region of India i.e. Gujarat, Maharastra and Rajasthan. The study made an attempt to analyse the profitability analysis of the RRBs from 2007-08 to 2011-12. The main objectives of the study were to analyse the interest coverage ratio, return on Equity, to examine noninterest income ratio and to study net interest margin ratio of selected RRBs during study period. The finding of the study revealed that selected bank of Rajasthan showed higher profitability then selected RRBs of Gujarat and Maharashtra.

\subsection{Resources of RRBs}

The sources of funds of RRBs comprise of owned fund, deposits, borrowings from NABARD, sponsor banks and other sources including SIDBI and National Housing Bank. NABARD also gives refinance for short term loans for crop and other farm related activities and also refinance to term loans for investment purpose. A Regional Rural Bank is jointly owned by the government of India, the government of concerned state and public sector bank which sponsored it. Each RRB has an authorised capital of Rs. 1 crore, and issued and paid up capital of Rs. 25 lakh. The share capital of 
52 | PRAGATI: Journal of Indian Economy, Volume 3, Issue 2

the RRB was subscribed by the Central government (50\%), the state government concerned (15\%) and the sponsoring commercial bank (35\%). There were five commercial banks, Punjab National Bank, State Bank of India, Syndicate Bank, United Bank of India and United Commercial Bank, which sponsored the RRBs.

Regional Rural Banks have been set up with the following objectives in mind:

(i) taking the banking services to the doorstep of rural people who are deprived from banking service; (ii) identifying the financial need especially in rural areas;(iii) making available institutional credit to the weaker sections of the society who had no access to cheaper loans and depend on the private money lenders; (iv) enhancing banking and financing facilities in backward or unbanked areas; (v) mobilising rural savings and channelising them for supporting productive activities in rural areas; (vi) providing finance to the weaker sections of society like small farmers, rural artisans, small entrepreneurs, rural labourers etc.; (vii) providing finance to Co-operative Societies, Primary Credit Societies, Agricultural Marketing Societies; (viii) generating employment opportunities in rural areas and bringing down the cost of providing credit to rural areas. (ix) enhancing and improving banking facilities to semi urban, rural and other untapped market.

\subsection{Objective, Data and Methodology}

The basic objective of this study is to analyse the growth and financial performance of RRBs in India from the period 2013 to 2016 based on some selected parameters like area coverage, profit and loss making RRBs, number of RRBs with accumulated losses, trend of profits and accumulated losses, overall position of non-performing assets and recovery rate. For the purpose of the study, we have mainly used secondary data collected from various journals, books and available websites related to regional rural banks. We have used percentage to analyse the data.

\subsection{Performance of RRBs}

The Regional Rural Banks have started operating in the country from October 2, 197 5. They have witnessed a tremendous expansion in respect of the branches, deposit and credit business, investment, borrowing, loan and advances etc., during 1975-2016. Growth and development of RRBs as well as financial performances during 2013-16 have been explained with the help of the following parameters (Table 1). 


\subsection{Branch network}

A perusal of Table 1 furnishes the expansion of RRBs in India during the period from 2013 to 2016. As a result of amalgamation, the number of registered RRBs has gradually been declining from 64 as on $31^{\text {st }}$ March, 2013 to 56 as on March, 2016. As far as branch network is concerned, it is found that branch network has gradually increased year by year. As on $31^{\text {st }}$ March, 2016, total number of RRBs were 56 which operated with a network of 20,904 branches where there were 17856 branches as on $31^{\text {st }}$ March, 2013. It is observed that during the period of 2013 to 2016, RRBs have increased by more than 17 per cent. The number of districts covered by RRBs in India as on $31^{\text {st }}$ March, 2013 was 635 and it progressively increased year by year and reached 644 districts in the end year of 2016.

Table 1: Performance of RRBs as on 31 March, 2016 (Amount in Rs. crore)

\begin{tabular}{|l|c|c|c|c|}
\hline Parameters & $\mathbf{2 0 1 3}$ & $\mathbf{2 0 1 4}$ & $\mathbf{2 0 1 5}$ & $\mathbf{2 0 1 6}$ \\
\hline No. of RRBs & 64 & 57 & 56 & 56 \\
\hline Branch network (no.) & 17856 & 19082 & 20024 & 20904 \\
\hline Districts covered by RRBs & 635 & 642 & 644 & 644 \\
\hline Share capital (Rs. crore) & 197 & 197 & 197 & 5196 \\
\hline Share capital deposit (Rs. crore) & 6001 & 6170 & 6175 & 1192 \\
\hline Reserves (Rs. crore) & 13247 & 15262 & 18712 & 21032 \\
\hline Deposits (Rs. crore) & 211488 & 239511 & 273018 & 315048 \\
\hline Borrowings (Rs. crore) & 38073 & 51208 & 59422 & 48110 \\
\hline Investments (Rs. crore) & 110683 & 110514 & 162781 & 210936 \\
\hline $\begin{array}{l}\text { Gross loans and advances outstanding } \\
\text { (Rs. crore) }\end{array}$ & 137078 & 218110 & 180955 & 207279 \\
\hline RRBs earning profit (no.) & & & & \\
\hline Amount of profit (A) (Rs. crore) & 2275 & 2694 & 2921 & 2556 \\
\hline RRBs incurring losses (No.) & 1 & 0 & 5 & 5 \\
\hline Amount of losses (B) (Rs. crore) & 2 & 0 & 176 & 122 \\
\hline Net profit of RRBs (A - B) (Rs. crore) & 2273 & 2694 & 2745 & 2434 \\
\hline Accumulated losses (Rs. crore) & 1091 & 949 & 1072 & 1030 \\
\hline RRBs with accumulated losses (No.) & 11 & 8 & 8 & 8 \\
\hline Recovery (\%) & 81.9 & 81.89 & 79.49 & 82.51 \\
\hline NPA to loans outstanding (\%) & 6.08 & 4.35 & 6.15 & 6.45 \\
\hline Net worth (Rs. crore) & 18354 & 21199 & 24011 & 26685 \\
\hline
\end{tabular}

Source: NABARD's Annual Report, 2013-16. 
54 | PRAGATI: Journal of Indian Economy, Volume 3, Issue 2

\subsection{Own fund}

Own fund is the sum total of share capital, share capital deposit and undistributed profit or reserves. The share capital is limited to rupees one crore for each RRBs. From Table 1, it can be seen that during 2012-13, own fund of the RRBs was Rs. 19445 crore and it stood at Rs. 27420 crore during 2015-16. Thus, we see that during the period of 2013-16, own fund of the RRBs has increased by over 41 per cent. The reserves also have witnessed an increase of around 59 per cent during the period of 2013-16.

\subsection{Deposit mobilisation}

Deposit mobilisation is a vital activity for a banking institution which determines its working and viability to a great extent. The higher the deposits, the higher will be the funds at the disposal of a bank to lend and earn profit. The success and efficiency of the banking sector depends on the extent to which it is able to mobilize the savings of the community in the form of deposits. Regional Rural Banks have a challenging role to play in this count. They have been able to mobilise rural savings to a considerable extend during the past years. The performance of the RRBs with reference to the deposits mobilized by them during the period 2013-2016, reveals that the total deposits of RRBs increased steadily and substantially from Rs. 211488 crore in 2013 to Rs. 273018 crore by 2015 and Rs. 315048 crore by the end of March 2016. If we compare the deposit of the RRBs during the period of 2013-2016, we see that around 49 per cent deposit has increased during this period.

\subsection{Borrowings}

The borrowing performance of RRBs has been shown in the Table 1. From the Table, it is found that borrowings of RRBs increased from Rs. 38073 crore as on $31^{\text {st }}$ March, 2013 to Rs. 48110 crore as on $31^{\text {st }}$ March 2016. It is observed that borrowings increased by 26.36 per cent during 2013 to 2016 .

\subsection{Investments}

As far as investment is concerned, it is found from Table 1 that the investments of RRBs increased from Rs. 110683 crore as on 31 March, 2013 to Rs. 210936 crore as on $31^{\text {st }}$ March, 2016 registering a growth of 90.57 per cent.

\subsection{Loans and advances}

Lending of RRBs was initially restricted to priority sector and it was in 1991 that this restriction had been lifted. Since then, RRBs have diversified into a wide range of 
non-priority sector advances including jewellery, consumer loans, deposit linked loans and housing loans, education loan. Still a target of 60 per cent of total credit has been fixed for the priority sector and 15 per cent for the weaker sections of the society. Regarding loans and advance outstanding it is seen from the table 1 that the loans and advance outstanding was Rs. 137078 crore as on March 31 2013 and it was Rs. 207279 crore as on $31^{\text {st }}$ March 2016. During this period, loans and advance outstanding increased by 51.21 per cent.

\subsection{Profit amount}

Table 1 shows the amount of profit of the RRBs. From the table it is found that the quantum of profit earned by profit making RRBs has increased from Rs. 2275 crore in 2013 to Rs. 2921 crore in 2015. However, the amount of profit has reduced from Rs. 2921 crore in 2015 to Rs. 2556 crore in 2016. Therefore, it is seen that amount of profit has reduced during this period.

\subsection{Net profit/loss}

The aggregate profit earned which stood at Rs. 2274 in 2012-13, Rs. 2921 crore in 2014-15 declined to Rs. 2556 crore during 2015-16. In 2012-13, aggregate losses of the RRBs were Rs. 2 crore. The aggregate losses declined from Rs. 177 crore during 2014-15 to Rs. 122 crore during 2015-16. However, overall net profit of RRBs as an agency declined from Rs. 2,745 crore as on 31 March 2015 to Rs. 2,434 crore as on 31 March 2016.

\subsection{Accumulated losses}

Accumulated loss has been a troublemaker since long for RRBs. There have been many efforts to wipeout or to reduce it, by all stakeholders from time to time. From Table 1, it can be seen that as on $31^{\text {st }}$ March 2013, accumulated losses of 11 out of the 64 RRBs was Rs. 1091 crore as against Rs.1030 crore (8 RRBs) as on $31^{\text {st }}$ March 2016. The accumulated loss decreased by Rs. 321 crore during the year under review. The number of RRBs that had accumulated losses reduced from 61 crore, i.e., around 6 per cent during the period 2013-16.

\subsection{Recovery performance}

As these banks are dealing with rural poor, who depend on unstable income, the low recovery of advances is quiet common among RRBs. Whatever be the reason for low recovery, it is deemed as the major factor behind the viability problems which the RRBs faced since its inception. The recovery performance of RRBs has been shown in 
Table 1. From the table, it is found that the recovery performance of RRBs increased from 81.9 per cent as on $31^{\text {st }}$ March 2013 to 82.51 per cent as on $31^{\text {st }}$ March 2016. Recovery performances of the RRBs have around the same during 2012-13 and 201314. However, during 2014-15, the recovery performance of the RRBs declined to 79.47 per cent. Again, the recovery performance of RRBs has been improved during 20152016.

\subsection{Non-performing assets (NPA)}

The non-performing asset (NPA) of RRBs stood at Rs. 7907 crore as on 31 March, 2013 (i.e., 5.65\%). The percentage of net NPA of RRBs has shown an increase from $2.98 \%$ to $3.40 \%$ during the year. The gross NPA of all RRB increased from 6.15 per cent, as on 31 March 2015 to 6.45 per cent as on 31 March 2016 (as per unaudited data). While 32 RRBs reported Gross NPAs less than 5 per cent as on 31 March 2015, 27 RRBs have reported Gross NPA less than 5 per cent as on 31 March 2016.

\subsection{Findings and Conclusion}

This paper focuses on the performance of Regional Rural Banks in respect of Indian economy during 2013-16. The variables like branch network, own fund, deposit mobilization, borrowings, loans and advances, investments, profit amount, net profit, loss, accumulated losses, recovery and movements of NPA have been examined to have an idea about the financial performance of RRBs. The review of the performance of RRBs during the period 2013-16 reveals that the number of RRBs has decreased from 64 as on March, 2013 to 56 as on March, 2016 due to amalgamation. However, the branches of RRBs increased during the period of 2013-2016. As on $31^{\text {st }}$ March, 2016, total number of RRBs were 56 which operated with a network of 20,904 branches where there were17856 branches as on $31^{\text {st }}$ March, 2013. The reserves also have witnessed an increase of around 59 per cent during the period of 2013-16. Regarding deposit mobilization it is found that around 49 per cent deposit has increased during the period 2013-16. It is observed that borrowing increased by 26.36 per cent during 2013 to 2016 . The growth of investments is 90.57 per cent. During this period, loans and advance outstanding increased by 51.21 per cent. It is seen that amount of profit and net profit of RRBs has increased 12.35 per cent and 7.08 per cent during this period respectively. Accumulated losses reduced around 6 per cent during this period. The recovery performance of RRBs has been improved during 2015-2016. The review of the performance of RRBs shows the good growth performance of RRBs for providing better banking services to the rural people. 
From the above analysis, it can be inferred that rapid expansion of RRBs has been able to reduce substantially the regional disparities in respect of banking facilities in India. The efforts made by RRBs in their branch expansion, deposit mobilisation, rural development and credit needs to weaker section, viz., small and marginal farmers and village artisans of rural areas, are appreciable. RRBs have successfully achieved their objective by taking banking facilities to the doorsteps of rural households particularly in banking deprived rural areas. Not only that, RRBs have been able to provide easy and cheaper credit to weaker rural poor who are dependent on non-institutional sources. Moreover, they have been able to generate employment in rural areas. To sum up, regional rural banks have served the weaker sections better than any other credit system in the country.

\section{References}

Agarwal, R.K. (1991). Evaluation of the Working of Regional Rural Banks: A Study of Prathma Bank of Rampur and Moradabad Districts of U.P. Metal Publications, New Delhi.

Bhatt, K.A. (2013). Profitability analysis of regional rural banks in India with special reference to Western region. International Journal of Research In Computer Application and Management, 3(8).

Datt, R \& Sundaram, K.P.M. (2009). Indian Economy. S. Chand and Company Ltd. New Delhi.

Ibrahim, S. (2010). Performance evaluation of regional rural banks in India, Business Research. Canadian Center of Science and Education. 3(4), 203-211.

Ishwar, P. (2011). A financial performance analysis of regional rural banks: Pre and post transformation. International Journal of Economics Research, 2(1): 142-151.

Sharma, U. (2013). Role of Credit Disbursement Policies of Regional Rural Banks in the Sustainable Development of H.P. Economy: An Empirical Study. International Journal of Marketing, Financial Services \& Management Research, 2(4).

Singh, A. K. (2015). Role of RRBs in the promotion of Self Help Groups in India: An Analytical study. International Journal of Scientific and Research Publications, 5(9). 
58 | PRAGATI: Journal of Indian Economy, Volume 3, Issue 2

Annual reports of NABARD (2007-08 to 2012-13). Retrieved from:

https://www.nabard.org/english/annualreport.asp

Selvakumar, M. (2010). Regional Rural Banks: Performance analysis. Indian Journal of Finance, 4(8): 3-19. 